\title{
The Research on the Relationship between National Traditional Sports and the Construction of Campus Network Culture
}

\author{
$\mathrm{Li} \mathrm{Li}$ \\ Shanxi Xueqian Normal University \\ Xian, China
}

\begin{abstract}
The National Traditional Sports was a very important part of the Chinese National Culture, it promoted the process of the Construction of Campus Network Culture. The Campus Network Culture was a special one which was built on the base of the campus culture. And it developed with the integration of the National Traditional Sports. This thesis mainly made a research on the relationship between National Traditional Sports and the Construction of Campus Network Culture and how the National Traditional Sports impact the Campus Network Culture.
\end{abstract}

Keywords-national traditional sports; campus network; culture

\section{INTRODUCTION}

The Chinese traditional national sports had the history of more than thousands of years before the formation of precipitation; it was not only the history and culture of precipitation, but also a symbol of Chinese national spirit. What is more, it also had the positive effects of physical fitness and moral training. The Chinese traditional national sports played a very important role in the process of the construction of campus network culture, it was not only enrich the campus teaching activities, but also inherited the our national traditional sports culture effectively, which promoted the construction and development of Harmonious Campus Culture. Therefore, it has a very important practical significance to study the co-relation between the traditional national sports and the campus network culture.

\section{THE GOOD IMPACT OF THE TRADITIONAL NATIONAL SPORTS ON THE CONSTRUCTION OF CAMPUS NETWORK CUlture}

\section{A. The Traditional National Sports Is Good to the Body and the Mental Pleasure}

Nowadays, there are about more than thousands of kinds of traditional forms of physical training in our country, such as wrestling, dragon dance, lion dance, swing, rowing and martial arts. Some of these kinds of traditional ethnic sports have originated from the myth, some are appeared in the process of people's daily lives, some are originated from the war, and the other from the animal's playing. In a word, every sport is different. In the big national festivals, people always carry out a variety of national traditional sports activities to commemorate them. Though these sports have diversified forms, they are simple and easy for people to learn and take part in. Some activities are dancing in the music, such as folk dance, some are in the voice of the people to carry out, such as the dragon boat, wrestling. In a sentence, all these kinds of sports and activities are good to the people's physical body and mental spirit. At the same time, through the introduction of the national culture and sports, we can build a more harmonious atmosphere for the students and make them more active to take part in these sports activities, promoting the construction of the campus network culture. During the process of taking part in the sports, the students can build their physical body and make them happier.

\section{B. Strengthen the Effective Infiltration of Moral Education}

Mao Zedong, a great man of our country, he once said the physical education has a close relationship with moral education. A Lot of the traditional national sports activities are carried out in the solemn ritual activities, therefore it has a higher requirement for the moral quality of sports participants. Meanwhile, it also prohibited the people who have moral corruption or bad behavior to participate in. All these sports activities have strict moral requirement. If you want to participate, you have to regulate their own behavior. Also, if we introduce the national traditional sports activities into the construction campus network culture, it can effectively improve students' moral sentiment and meet the needs of the campus network culture.

\section{Stick to the "Harmony between Man and Nature" Concept}

The traditional national sports are an important part of Chinese traditional culture, which is bound to be influenced by traditional culture. China's traditional culture has always stressed that the harmony between man and nature, so traditional national sports should also stick to this concept. Taiji which is one of Chinese national traditional sport, it is mainly uphold the idea of "Killing with Kindness, The best defence is offence"; Wushu uphold the idea of "learn from each other and do not hurt people"; Weiqi has the idea of

"balance of yin and Yang". Though different kinds of sports have different ideas, they have one thing in common, that is 
harmony. If we integrated these kinds of traditional sports into the construction of the campus network culture, it can strengthen students' idea of "perfect harmony between the human and the nature." It also help students more and more love nature, love society, so as to meet the needs of the construction of the campus network culture.

\section{The Cultivation of Students' Sense of Responsibility, Sense of Identity, Sense of Honor}

Different traditional national sports originated from different places and nations; therefore have different nation's unique characteristics. Such as the "Guozhuang dance" from Tibetan, the "independence bamboo drift" from Gelao, the "mining the moon" from Miao, the "long drum dance" from North Korean. All these kinds of national sports can represent their nation's characteristics, once we say the national sports we can immediately think of the nation it represent. People of the same nation dancing and singing together, participating the same kind of sports, it not only can effectively enhance the sense of responsibility for the nation and people's sense of identity, but also effectively enhance their sense of national honor. In one sentence, all these kinds of traditional national sports have their unique character. If we integrated these kinds of traditional sports into the construction of the campus network culture, it can effectively improve students' sense of responsibility, sense of identity, sense of honor, motivate their love to their country.

\section{THE EFFECTIVE WAY OF INTEGRATING NATIONAL TRADITIONAL SPORTS INTO THE CONSTRUCTION OF CAMPUS NETWORK CULTURE}

\section{A. PE Class}

According to the statistic, lots of national schools are set up with physical education departments, but few of them have the national traditional sports. Therefore, if we integrate national traditional sports into the PE class, it can enrich the content of physical education courses. This also a effective way of inheritance and development of national traditional sports culture. We can find that the ethnic minority students accounted for more than half of the proportion of students in the national school. So we can take good advantage of this opportunity and integrate national traditional sports into the PE class, which can promote the construction of the campus culture.

\section{B. Extracurricular Activities}

Extracurricular sports activities can reflect the situation of the school sports in a great extent. However, the extracurricular sports activities in many ethnic colleges are in disorder. What is more, the introduction of modern sports has directly disturbed the effective development of national traditional sports activities. In some PE classes, though the students do not like it, they have no choice but to accept it. But in the extracurricular sports activities, the students can chose their favorite spots, which is also good to the construction of the campus culture. Meanwhile, the school can also provide policy support and guide the students to actively participate in the activities of these national sports activities, in order to motivate their enthusiasm and the initiative. By doing this, we can promote the construction of the campus network culture.

\section{Sports Associations}

The sports association is a kind of non-profit sports organization of the school which is organized by the student who love sports; it plays a very positive role in promoting the he construction of the campus network culture. But in the real life, there are few national traditional sports associations in the colleague and the university, and few universities have the special traditional sports associations like "Guozhuang Dance". This situation will restrict our national traditional sports culture inheritance not so effective. Therefore, we must make reasonable use of sports associations and actively carry out the traditional national sports associations, so as to promote the smooth implementation of the construction of campus network culture.

\section{Sports Competitions}

Competition activity is used to detect the specific circumstances of the school national traditional sports. A lot colleagues regularly hold spring and autumn games every year. Though these sports activities are mainly based on Modern Sports, there are still national traditional sports in the games, such as Gyro, Cuqiu and Yajia etc. This will not only make a good inheritance of our national traditional sports culture, but also makes the sport more rich and colorful. While in the process of participating of these sports activities, the students can get a good competition and entertainment. Through doing this, we can promote the smooth implementation of the construction of campus network culture.

\section{ANALYSIS ON THE RESEARCH RESULTS OF NATIONAL TRADITIONAL SPORTS IN THE CONSTRUCTION OF CAMPUS NETWORK CULTURE}

\section{A. Contribute to the School Sports Material Culture Construction}

School sports material culture construction is mainly refers to the construction of school sports facilities, sports equipment, building construction. These are the basement of the construction of the school sports material culture. Although the material itself is the results of the people, we also can see that there are strong senses of sports culture in it. It also carries people's awareness of sports culture as well as wisdom. Modern education emphasizes the humanistic concern, which also shows that education should be realized in the natural environment. National traditional sports are an example of the combination of education with life and nature. Therefore, it plays a positive role for the inheritance of national traditional sports culture. So, the construction of campus network culture must be coordinated with the construction of sports material and spiritual culture, which is good to promote the construction of campus network culture. 


\section{B. Help to Improve the Construction of Campus Sports System Culture}

Campus sports system culture construction, refers to a variety of sports related to rules and regulations, it has the character of normative, scientific, restrictive and stable. It is one of the main means to restrain students' sports culture. Only we constantly improve and perfect the campus sports culture management system and actively coordinate the relationship between each link, can we make sure the construction of campus network culture goes on smoothly.

\section{Help to Strengthen the Construction of Campus Sports Behavior Culture}

Campus sports behavior culture is an important part of campus culture; it can also reflect the culture of the school precipitation. But this part of the content is the need for students to work together to build. A person's excellence is not his good behavior, but also he must have a good behavior habits. Whether the school is excellent or not, it is not a moment of good behavior and appearance of show, it should also belong to the school of a spirit or a kind of cultural behavior. The conception of campus culture is only recognized by most people can it become the whole school students' values. In order to influence the behavior of students from a certain extent, it is to form a good behavior culture through the behavior of students.

\section{Helps to Enrich the Campus Sports Spiritual Culture Construction}

Sports as a sport, it is not only a kind of campus culture, but also a kind of charm. Especially the national traditional sports in our country contains a lot of beautiful factors, it contains the current people's pursuit of the concept of excellent culture. At the same time, the source, area and environment of the national traditional sports are different, it can meet the different needs of the students. It also can promote national traditional sports and students' psychological to be effectively unified, so as to make them more actively involved in the national traditional sports. This will have a more positive impact on the student's ideological and moral sentiments, So as to help them form the correct concept of sports.

\section{Suggestions on the National Traditional Sports on CAMPus NeTwORK Culture CONSTRUCTION}

\section{A. Inherit and Carry Forward the National Traditional Sports Culture}

Traditional sports contains rich ancient culture and cultural achievements, it has strong historical value and is a very important part of our national traditional culture. However, National traditional sports still have the character of strong entertainment and fitness, which has a certain influence. Although our society has achieved good development, but it still needs to inherit and carry forward the culture of national traditional sports, which promote the smooth implementation of the construction of campus network culture.

\section{B. To Carry out Some Traditional National Sports Culture and Arts Festival Activities}

We can also actively carry out some traditional national sports culture and arts festival activities, and actively introduce some national traditional sports. This will not only enrich the campus sports and cultural activities, but also can strengthen the school teachers and students understanding and understanding of sports culture. In order to effectively inherit and promote the traditional culture, and promote the smooth construction of the campus network culture.

\section{Combined with the Local Customs and Habits to Actively Carry out Some National Sports}

National traditional sports culture has a strong regional character. Therefore, it is necessary to combine the customs and habits of the region to actively carry out some national sports with national characteristics. This will not only lead to better inheritance of regional national characteristics, but also to promote the effective integration of different ethnic cultures, which can promote the smooth construction of the campus network culture.

\section{Strengthen the Effective Construction of National Traditional Sports Talents}

If we want to strengthen the effective construction of national traditional sports talents, we must constantly strengthen their theoretical knowledge learning and practical ability training, which can promote the smooth construction of the campus network culture. We can do the following things: first of all, try to open some national traditional sports courses in schools; secondly, add some content to the National Traditional Sports in the school public physical education course; third, we can hold some training courses which effectively improve the teaching level of the existing teachers.

In one sentence, innovation is the soul of a nation's progress. Therefore, it is necessary to study the national traditional sports on campus network culture construction effectively, so that we can promote the smooth construction of the campus network culture and promote the healthy development of national traditional sports culture in our country.

\section{REFERENCES}

[1] Yelena Karavayeva. The Understanding of Physical Education. The $17^{\text {th }} \quad$ International“Olympic Competitive Sports and Popular Sports"Scientific Congress Abstract. 2013.

[2] The analysis of the PE curriculum. Proceedings of 2008 International Convention on Science, Education and Medicine in Sport (Volume I). 2008.

[3] Suherman,. Teachers' implication on the development of curriculum and teaching models in physical education. Proceedings of 2008 International Convention on Science, Education and Medicine in Sport (Volume I) 2008.

[4] Jia-jun XIANG, Zhi-jin HE. The Train of Thought and Method of Working on the Curriculum Framework of the PE Major. Proceedings of the Xi'an 2012 International Conference of Sport Science \& Physical Education Volume II : Physical Education and Innovation. 2012.

[5] Linghe KONG, Anna SUN. A Comparison and Analysis on Curriculum Setup of Physical Education in Higher Institutions of China 
Proceedings of the Xi'an 2012 International Conference of Sport Science \& Physical Education Volume I : Science and Innovation in Sport. 2012.

[6] Ying hao LU, Wei zhong WANG. Improving the Teaching Quality of Physical Education in University by Course construction. Proceedings of the Xi'an 2012 International Conference of Sport Science \& Physical Education Volume III: Physical Education and Health. 2012.

[7] Ennis, C. Reproducibility of effect from a curriculum intervention study in physical education. Proceedings of 2008 International Convention on Science, Education and Medicine in Sport (Volume I ) .2008 .

[8] Analysis of the Current Teaching Situation and Countermeasures of Yoga Course in Anyang Institute of Technology. Proceedings of 2010 International Conference on Sport Medicine, Sport Science, and Computer Science (SMSSCS 2010). 2010.

[9] A comparison of college physical education curriculum between China and foreign countries. Proceedings of 2008 International Convention on Science,Education and Medicine in Sport (Volume I) . 2008.

[10] Kang Fan. Planning and Measures of Public Curriculum of Physical Education in University.. 2013.

[11] Li Lin. Effective classroom teaching physical education evaluation. China Education Innovation Herald . 2011.

[12] Ji Yuanbo.Expo physical education class teaching efficiency. Sports on the background of new curriculum . 2011.

[13] Zhang Lining. Pay attention to sports teaching and build "effective teaching". Modern Reading (EDUCATION EDITION) . 2011.

[14] Liu Junxia, Chen Yuxia. New Curriculum Effective Teaching . 2011

[15] Chen Kun.How to carry out efficient sports teaching. The Friends of Students (junior middle school) . 2011

[16] Shang Wenjin.Constructing effective classroom teaching of middle school sports. Sport. 2011.

[17] Shannon C E, Weaver W.The Mathematical Theory of Communication. 1949.

[18] Huang Xiaochuan. New media landscape of public relations. PR Magazine . 2009.

[19] Kuang Wenbo.New media is the mainstream media. 2011.

[20] Wu Yinsheng, Mei Jianbing.Some inspiration for the rapid development and psychological warfare in the use of social media. National Defense Science andTechnology . 2011.

[21] Li Ting. Network technology assisted applications on professional teaching. Journal of Wuxi education institute . 2006.

[22] W. Howard Levie, Richard Lentz. Effects of text illustrations: A review of research. Educational Communication \& Technology . 1982 (4).

[23] Darla M Castelli, Leah Fiorentino. Physical Education Technology Playbook. 2008.

[24] Dale,E. Audiovisual Methods in Teaching . 1969.

[25] AECT.The Field of Educational Technology:A Statement of Definition. Audio-Visual Instruction. 1972.

[26] Sugiyono. Metode Penelitian Pendidikan (pendekatan kuantitatif, kualitatif dan R\&D). 2010

[27] Yusuf,M.O.Information and communication technology and education: Analysing the Nigerian national policy for information technology. International Education Journal . 2005.

[28] Ananta Tri Prasetya.Making Of Volleyball Technique Learning As Interactive Multimedia Using Adobe Flash Media.. 2012.

[29] Arikunto,Suharsimi.Prosedur Penelitian: A Practice Approach. Edisi Revisi VI. 2006. 